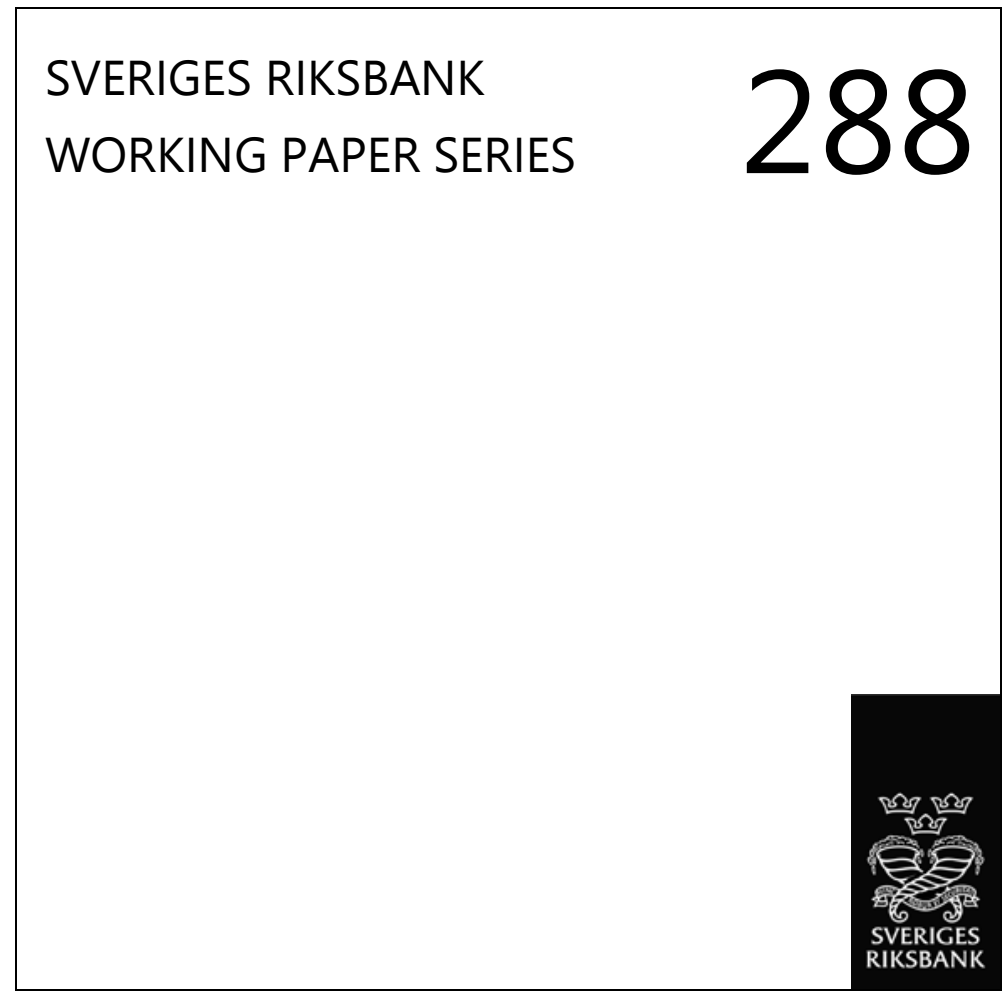

\title{
Does Trading Anonymously Enhance Liquidity?
}

Patrick J. Dennis and Patrik Sandås

October 2014 


\section{WORKING PAPERS ARE OBTAINABLE FROM}

Sveriges Riksbank • Information Riksbank • SE-103 37 Stockholm

Fax international: +4687870526

Telephone international: +4687870100

E-mail: info@riksbank.se

The Working Paper series presents reports on matters in the sphere of activities of the Riksbank that are considered to be of interest to a wider public.

The papers are to be regarded as reports on ongoing studies and the authors will be pleased to receive comments.

The views expressed in Working Papers are solely the responsibility of the authors and should not to be interpreted as reflecting the views of the Executive Board of Sveriges Riksbank. 


\title{
Does Trading Anonymously Enhance Liquidity?*
}

\author{
Patrick J. Dennis ${ }^{\dagger} \quad$ Patrik Sandås ${ }^{\ddagger}$ \\ Sveriges Riksbank Working Paper Series \\ No. 288 \\ October 2014
}

\begin{abstract}
Anonymous trading is the norm in today's financial markets but there are a few exceptions. We study one such case, the OMX Nordic Exchanges (Stockholm, Helsinki, Copenhagen, and Reykjavik) that have traditionally been more transparent than most other markets. On June 2, 2008 OMX Nordic switched to making post-trade reporting anonymous for some of their markets. We exploit this quasinatural experiment to investigate the impact this change had on liquidity and trading behavior. Our difference-in-difference method reveals a modest, though statistically insignificant, 14 basis point improvement in the quoted spread under the post-trade anonymous regime. The price impact of a trade decreased by a statistically significant four basis points for seller-initiated trades and did not change for buyer-initiated trades.
\end{abstract}

JEL Classifications: G10, G15, G14

Keywords: Anonymity; Transparency; Liquidity; Broker ID

${ }^{*}$ We are grateful for financial support from SIFR, the McIntire Foundation, and NASDAQ OMX Nordic and for comments from Andras Vajlok, Mika Koskinen, and Petter Dahlström. The views expressed in this paper are solely the responsibility of the authors and and should not be interpreted as reflecting the views of the Executive Board of Sveriges Riksbank.

${ }^{\dagger}$ McIntire School of Commerce, University of Virginia, Charlottesville, VA, 22904. Phone: 434-9244050, Email: pjd9v@virginia.edu

${ }^{\ddagger}$ McIntire School of Commerce, University of Virginia, Charlottesville, VA, 22904. Phone: 434-2432289. Email: patriks@virginia.edu. Sandås is a SIFR research affiliate. 


\section{Introduction}

Is market quality better when the counter-party is unknown (anonymous) or known (transparent)? Post-trade anonymity was implemented by the OMX Nordic Exchange in Helsinki, Reykjavik, and Stockholm on June 2, 2008. The switch to anonymity applied to all equity-related markets in Helsinki, Reykjavik and the five most traded stocks in Stockholm. Under the new post-trade anonymous regime the broker identity was removed from all market data feeds. It was, however, available after the close of each trading day to all members. Stocks in Stockholm, except for the five most traded ones, and all stocks in Copenhagen continued to trade with broker identities for each trade being part of the market feed. The implementation of the change therefore created a quasi-natural experiment on the effects of anonymity with stocks in Helsinki, Reykjavik and the top five in Stockholm forming the treatment group that became anonymous and the remaining ones in Stockholm and all those in Copenhagen forming the control group that remained transparent. ${ }^{1}$

We find that those stocks that became anonymous, relative to the control group that did not, experienced a modest, though statistically insignificant, decrease in quoted spread of 14 basis points. We also find that the price impact of a trade, defined as the percentage change in the quote midpoint five minutes after a trade takes place, decreased by a statistically significant four basis points for seller-initiated trades and did not change for buyer-initiated trades. Taken together, the switch to anonymity did not hurt and, in fact, slightly improved market quality.

A number of studies have investigated these type of changes but to our knowledge most

\footnotetext{
${ }^{1}$ There are in fact a few shares that experienced a true natural experiment. The shares of Nordea, Tieto and Stora Enso are traded in Stockholm and Helsinki, and in the case of Nordea, in Copenhagen as well. For these companies trading became anonymous in at least one market but stayed transparent in at least one of them due to one set being traded in Stockholm (outside the top five) and one in Copenhagen where all stayed transparent.
} 
changes have not had a natural control group. The common direction for changes has been to remove the broker identities, i.e., switch to some form of post-trade anonymity in trade reporting. The introduction of post-trade anonymity has often been a natural consequence of the introduction of Central Counterparty (CCP) clearing systems to replace bilateral clearing.

Studies by Hachmeister and Schiereck (2010) and Marsden et al. (2011) investigate the removal of broker identities on the German and New Zealand exchanges for 30 and 41 stocks, respectively. Hachmeister and Schiereck (2010) find significant improvements in liquidity while Marsden et al. (2011) find more modest gains and initially finds spreads widening after the event. Both of these studies examine an event but do not have a control group. Friederich and Payne (2011) study the switch to anonymity at the London SETS market and document liquidity improvements for a larger sample. Friederich and Payne (2011) differs from the first two in that they do use a control sample and apply difference-in-difference regression techniques, but their control sample is from a different market (SEAQ versus SETS). Another difference between the change studied by Friederich and Payne (2011) and the one we study is that the change in Friederich and Payne (2011) involves going from bilateral exchange of counter party information to complete anonymity. That change is different than the one we study in that in our case the transparent regime involves all members seeing the trade counter party information. We are to our knowledge the first to study this type of change in a quasi-natural experimental setting.

Electronic markets often started out more transparent than they are today. For some markets the transition towards greater anonymity has involved an earlier step in which the order book became anonymous, i.e., the broker identities associated with the limit orders in the order book were removed. This is true as well for the NASDAQ OMX Nordic's exchanges but that change took place many years ago. Foucault et al. (2007) 
examine the switch to pre-trade anonymity at the Paris Bourse and report improvements in liquidity. Related studies by Comerton-Forde and Tang (2009), Frino et al. (2010), and Comerton-Forde et al. (2005) examine the effects of changes in the transparency of different markets with respect to the anonymity dimension of transparency.

A different strand of the literature asks whether displaying broker identities helps facilitate tacit collusion. In this case anonymity would make the market more competitive hence improving liquidity. Simaan et al. (2003) document that market makers are more likely to quote on odd ticks and to narrow the inside spread when they can do so anonymously on a different platform. ${ }^{2}$

The theoretical literature is split on the issue of anonymity. Fishman and Hagerty (1995) show that disclosure of insider traders will create a new source of profitable trading opportunities for the insider because the market does not know whether he was trading on information or not. Huddart et al. (2001) extends Kyle (1985) to incorporate the insider disclosing his trades after the fact, i.e., post-trade transparency versus anonymity. They find that price discovery is accelerated and insider profits reduced and hence spreads are narrower under transparency. Rindi (2008) uses a Grossman and Stiglitz (1980) framework and shows that liquidity can be enhance or impaired depending on whether the information acquisition is exogenous or endogenous, but her focus is on pre-trade transparency. Foucault et al. (2007) examine pre-trade anonymity, introduce informed trading on volatility signals and find that anonymity is associated with improved liquidity. In their discussion of market transparency Foucault et al. (2013) point out that posttrade anonymity generates higher rents for informed traders. They point out that rent seeking and lobbying may tilt the market structure to favor some players over others. Foucault et al. (2013) also highlight that one cannot rely on competition between markets

\footnotetext{
${ }^{2}$ Other studies examine situations where the markets are parallel as in Grammig et al. (2001) and Comerton-Forde et al. (2011) or study markets where the disclosure of broker identities is periodic (twice a day disclosure of the top brokers buying and selling) as in Pham et al. (2014) and Pham (2014).
} 
to correct possible problems. Overall the theory in this area does not point to a clear prediction for liquidity changes for the kind of change we examine..

Related questions are how and why post-trade anonymity matters. The natural starting point is to ask whether the broker identities contain useful information in predicting short term order flow and price movements. Frino et al. (2010) and Lepone et al. (2012) examine the information content of broker identities and find that the market attributes greater information content to successive unidirectional trades when a single broker rather than by different brokers. Menkhoff and Schmeling (2010) report similar findings for the foreign exchange market. Linnainmaa and Saar (2012) combine data on the identities of individual investors with order flow data and find that while individual investors can and do follow mixed strategies to some extent, the broker identities are still predictive signals. Based on this strand of the literature one would predict an improvement in liquidity for the treatment group of stocks.

\section{Institutional Setting and Our Sample}

\subsection{Institutional Setting}

On June 2, 2008, OMX Nordic Exchange started post-trade anonymous trading in some of its markets. The Helsinki and the Reykjavik exchanges implemented anonymity across all equity-related markets. The broker identity was removed from the the market data feed and SAXESS trade ticker. In Stockholm, the change was limited to the five most actively traded stocks; these were Ericsson B, Volvo B, Telia Sonera, Nordea, and H\&M B. These five stocks represented roughly $33 \%$ of total turnover in Stockholm based on turnover figures from the previous year. The counter party information was to be transmitted to all members as of 18:00 hours every day. There was no change to posttrade transparency on the Copenhagen exchange or the Stockholm exchange with the 
exception of the five most active stocks listed above.

The motivation for the changes given by the exchange management was that anonymous trading was believed to lower trading costs, reduce market impact, and increase competitiveness. Some proponents of the change cited the increased used of algorithms that are used to spot patterns in trading. Those who objected often cited counter-party search costs and execution control. Another argument given for transparency was that it leveled the playing field for smaller participants: larger members could already observe a representative sample of the order flow but the disclosure of broker identities behind trades was particularly helpful for smaller members.

Coincidentally there was a membership vote which was close and explains how the quasi-natural experiment came to be. The vote split so that local members based in the Nordic countries were mostly against and international members represented by the Investment Management Association in London were mostly in favor of the proposal. The relative balance between these two groups explains where the change was implemented. The London based member firm have a bigger market share in both Helsinki and Reykjavik, whereas the local members have a bigger market share in Stockholm and even more so in Copenhagen.

The implementation meant that the real time information on counter parties to trade was removed from the market feed. Trade by trade counter-party information was to be published end of trading day. ${ }^{3}$

\subsection{Our Sample}

Data on trades and the limit order book state is provided by OMX market research. Our sample consists of observations on 684 equities in Copenhagen, Helsinki, Stockholm

\footnotetext{
${ }^{3}$ The switch to post-trade anonymity was later reversed. In April 2009, the change was largely rolled back and that reflected a power shift from the members representing international clients to members representing local clients. We are in the process of acquiring data for that second period (2009) to study the shift to a more transparent regime.
} 
and Reykjavik from March 3, 2008 to September 26, $2008^{4}$.

On June 2, 2008 all equities that trade in Helsinki and Reykjavik as well as five equities that trade in Stockholm became post-trade anonymous, accounting for 174 firms in our sample. The remaining equities in Stockholm and all those in Copenhagen did not become post-trade anonymous, accounting for the remaining 510 firms. Not all firms have trades over our entire sample period; the average number of firms per day is 653 . To exclude any confounding effects due to the introduction of anonymity, we exclude observations in a two-week window from May 25, 2008 to June 9, 2008 surrounding the event date. This leaves a total of 112 trading days: 54 days before the event and 58 days after the event.

Historical daily foreign exchange rates were obtained from the European Central Bank $^{5}$ and merged with the OMX data. These rates are used to convert prices in Swedish Krona, Icelandic Krona and Danish Krone to Euro. Daily Euro volume for each firm is computed by summing the daily Euro value of all trades.

The inside bid-ask midpoint is computed for each firm every 15 minutes and these are used to construct the daily return standard deviation. Prices for each firm are sampled every 15 minutes, shares outstanding are obtained from Nasdaq OMX ${ }^{6}$. Shares outstanding is multiplied by the firm's average daily price to compute the firm's market value of equity in Euro.

Table 1 reports the breakdown of member firms in groups according to which submarkets they belong to. For example, the HCS label refers to members of the Helsinki, Copenhagen, and Stockholm, exchanges and there are a total of 36 member firms in this group. Their market share based on turnover for the January-September 2008 period was

\footnotetext{
${ }^{4}$ Due to a data collection omission, we are missing order book data from July 14, 2008 to July 18, 2008. The omission is technical and unrelated to market dynamics and should not bias our findings in any way.

${ }^{5}$ https://www.ecb.europa.eu/stats/exchange/eurofxref/html/index.en.html

${ }^{6}$ http://www . nasdaqomx. com/transactions/markets/nordic/statistics
} 
just over $50 \%$ and their market share based on the number of trades was around $56 \%$. A total of 11 members belong to all four exchanges, Helsinki, Stockholm, Copenhagen, and Reykjavik, and they account for $26 \%$ of turnover and $22 \%$ of the number of trades. The third largest market share group are the 15 firms that are members of Helsinki and Stockholm accounting for $15 \%$ of turnover and $23 \%$ of trades. Together these 52 firms account for the bulk of the trading activity across the four markets. While the smaller sub-groups of firms that do not belong to HCS, HCSR or HS do not account for much of of the total turnover and number of trades they account for a bit more in terms of the local exchange turnover and trade figures. As one would expect member firms who are based on London primarily show up in the first three groups.

Nordic Exchange Member Market Shares

\begin{tabular}{cccc}
\hline Members of & Number of & Market Share \%(turnover EUR) & Market Share \%(trades) \\
\hline HCS & 36 & 50.22 & 56.13 \\
HCSR & 11 & 26.34 & 22.28 \\
HS & 15 & 15.50 & 23.50 \\
C & 20 & 3.22 & 2.90 \\
CSR & 2 & 1.95 & 1.77 \\
H & 2 & 0.95 & 1.44 \\
CS & 6 & 0.87 & 1.28 \\
CR & 3 & 0.43 & 0.08 \\
S & 17 & 0.37 & 0.59 \\
R & 10 & 0.11 & 0.02 \\
HSR & 2 & 0.05 & 0.01 \\
Sum & 124 & 100.0 & 100
\end{tabular}

Table 1: The table reports the breakdown of members of the different Nordic Exchanges by groups according to whether the group members are members of all four exchanges (HCSR, Helsinki=H, Copenhagen $=\mathrm{C}$, Stockholm $=\mathrm{S}$, and Reykjavik=R) or some combination thereof, the number of group members as of September 2008, the aggregate market share of group based on turnover (EUR) or number of trades. 


\section{Methodology}

We apply the difference-in-difference regression analysis as discussed in Angrist and Pischke (2009). ${ }^{7}$

\section{Results}

\subsection{Spreads}

Average quoted bid-ask spreads are computed for all firms on all days by computing the spread every 15 minutes throughout the trading day and averaging for each firm-day.

The unconditional mean (median) spread for all firm days in the entire sample is 295 (155) basis points.

Table 2 reports the spread conditional on the firm's market capitalization size decreases quickly. The large average spread is high due to the large spread in firms with small market capitalization; the average spread for the firms in the largest market capitalization quintile is $56 \mathrm{bp}$.

\begin{tabular}{ccc}
\hline Quintile & Mean MVE (Million Euro) & Mean Spread (bp) \\
\hline Lowest & 17 & 639 \\
2 & 58 & 370 \\
3 & 141 & 254 \\
4 & 470 & 156 \\
Highest & 5,930 & 56 \\
\hline
\end{tabular}

Table 2: All firm-day observations are sorted into quintiles based on the market value of equity for that day and the average quoted spread is computed for each quintile.

Table 3 contains the mean spread before and after the event date for those firms that became anonymous on June 2, 2008 (the treatment group) and those firms that did not

\footnotetext{
${ }^{7}$ Examples of papers that use difference-in-difference regression analysis are Card and Krueger (1994) and Derrien and Kecskes (2013).
} 
become anonymous (the control group). Table 3 is meant to describe what happened to the average spread; standard errors will be reported in the regression analysis.

Panel A contains the average spread change for all firms in the treatment and control groups. The overall effect of anonymity appears to be small. Those firms that became anonymous had a increase in average spread of $100 \mathrm{bp}$, while those that did not become anonymous has an increase of $74 \mathrm{bp}$, for a difference in difference of $100-74=26 \mathrm{bp}$. While the average spread for all firms increased, the increase in spread is conditional on the firm's market capitalization. Panels B, C and D contain firms sorted into terciles based on market capitalization. The treatment group in the lowest market capitalization tercile (Panel B) had the largest increase in spread, from 469 to 715 basis points, while the treatment group in the in the highest mve tercile (Panel D) had a small decrease in spread from 84 to 67 b.p.. With the exception of the small firms, the increase in spread for the treatment groups was similar in magnitude to that of the control group, suggesting that anonymity didn't impact the spread that much.

To draw inferences, we use a regression to estimate a difference-in-difference model of the following form:

$$
s_{i t}=\alpha_{0}+\alpha_{1} d_{i}^{c}+\alpha_{2} d_{t}^{a}+\alpha_{3} d_{i}^{c} d_{t}^{a}+\alpha_{4} m_{i t}+\alpha_{5} \sigma_{i t}+\alpha_{6} v_{i t}+\epsilon_{i t} .
$$

The dependent variable, $s_{i t}$, is the the average daily inside spread for firm firm $i$ on day $t$ in basis points. The dummy variable $d^{c}$ is 1 if the firm is in the treatment group (did become anonymous) and 0 otherwise. The dummy variable $d^{a}$ is 1 if the observation occurs after the anonymity event on June 2, 2008 and 0 if the observation occurs before that date. For firm $i$ on day $t, m_{i t}$ is the logarithm of the market value of equity in Euro, $\sigma_{i t}$ is the daily volatility of returns using quote midpoints sampled every 15 minutes, and $v_{i t}$ is volume of shares traded in billions of Euro. The coefficient on the interacted 
Panel A: All firms

\begin{tabular}{cccc}
\hline & Anonymous (treatment, $t$ ) & Non-anonymous (control, $c$ ) & Difference $(t-c)$ \\
\hline Before $(b)$ & 234 & 281 & -47 \\
After $(a)$ & 334 & 355 & -21 \\
\hline Difference $(a-b)$ & 100 & 74 & \\
\hline
\end{tabular}

Panel B: Lowest market cap tercile, $\mathrm{MVE}=29$ million Euro

\begin{tabular}{cccc}
\hline & Anonymous (treatment, $t$ ) & Non-anonymous (control, $c$ ) & Difference $(t-c)$ \\
\hline Before $(b)$ & 469 & 529 & -60 \\
After $(a)$ & 715 & 618 & 97 \\
\hline Difference $(a-b)$ & 246 & 89 & \\
\hline
\end{tabular}

Panel C: Middle market cap tercile, MVE $=146$ million Euro

\begin{tabular}{cccc}
\hline & Anonymous (treatment, $t$ ) & Non-anonymous (control, $c$ ) & Difference $(t-c)$ \\
\hline Before $(b)$ & 194 & 228 & -34 \\
After $(a)$ & 253 & 295 & -42 \\
\hline Difference $(a-b)$ & 59 & 67 & \\
\hline
\end{tabular}

Panel C: Highest market cap tercile, MVE $=3,390$ million Euro

\begin{tabular}{cccc}
\hline & Anonymous (treatment, $t$ ) & Non-anonymous (control, $c)$ & Difference $(t-c)$ \\
\hline Before $(b)$ & 84 & 95 & -11 \\
After $(a)$ & 67 & 111 & -44 \\
\hline Difference $(a-b)$ & -17 & 16 & \\
\hline
\end{tabular}

Table 3: Average daily quoted spread, sampled at 15-minute intervals, for those firms that became anonymous on June 2, 2008 (the treatment group) and those firms that did not become anonymous (the control group) before and after the event date. Results are show for all firms and for firms sorted by market value of equity terciles.

dummies, $\alpha_{3}$, represents the change in spread for the treatment group (those firms that became anonymous after June 2) relative to the control group.

The three control variables are included since spreads are typically smaller for large firms, firms that have high volume and firms that have low return volatility. Table 4 shows the correlations between these variables. While larger firms and firms with higher volume are associated with lower spreads, the correlation with return volatility is close to 0. Quintile sorts by return volatility show a "U" shaped pattern where spreads are lowest for the middle return volatility quintile and higher for the smallest and largest quintiles. The regressions that follow are robust to the inclusion or exclusion of return volatility; it 
is reported to be consisted with other studies such as Friederich and Payne (2011). The control variables all have low correlations with each other, so multicolinearity will not be a problem.

\begin{tabular}{lcccc}
\hline & Spread & $\begin{array}{c}\text { Log Market } \\
\text { Value Equity }\end{array}$ & $\begin{array}{c}\text { Return } \\
\text { Volatility }\end{array}$ & Volume \\
& $s$ & $m$ & $\sigma$ & $v$ \\
\hline Spread $(s)$ & 1.0000 & & & \\
Log Market Value Equity $(m)$ & -0.4735 & 1.0000 & & \\
Return Volatility $(\sigma)$ & -0.0592 & 0.2676 & 1.0000 & \\
Volume $(v)$ & -0.1162 & 0.3778 & 0.4467 & 1.0000 \\
\hline
\end{tabular}

Table 4: Correlations between the spread and control variables.

While ordinary least squares (OLS) will give consistent estimates for the parameters in difference-in-difference models, standard errors can be biased downward (Bertrand et al. (2004)). Errors may be serially correlated errors resulting from a firm's above average spread one day to be followed by an above average spread the next day. Errors may also be cross-sectionally correlated if there is an event on a particular day that causes spreads on the equity of two or more firms to be above average. Since errors may be correlated along two dimensions (time and firm), we use the approach of Thompson (2011). Table 9 in the Appendix illustrates the effect of not correcting standard errors to account for these correlations. First, standard errors are obtained by estimating the regression and computing the variance-covariance matrix for the coefficients by clustering on firm $i$. Second, the variance-covariance matrix is computed by clustering on date $t$. Last, the variance-covariance matrix from a heteroscedasticity-robust OLS regression without clustering estimated and this matrix is subtracted from the sum of the matrices clustering along firm and time. This eliminates the double-counting of variances on the diagonals that would result if the two variance-covariance matrices from the clustering regressions were simply summed. 
Results from the regression are shown in Table 5. The coefficient on the interacted dummies, $d^{c} d^{a}$, represents how much the spread changed for those firms that became anonymous $\left(d^{c}=1\right)$ after June $2,2008\left(d^{a}=1\right)$. The estimate of -13.51 is marginally significant (t-statistic of -1.48), indicating some evidence of a decrease in spread when the treatment group became anonymous. Economically the decrease of 14 basis points suggests there was an effect. In future version we will interact the dummy for post period and anonymity with the size control to examine whether the effect was different for small and large companies. The descriptive statistics reported in Table 3 provides some indication of a different effect for the smallest versus largest stocks.

\begin{tabular}{lrr}
\hline Variable & Coefficient estimate & t-stat \\
\hline Constant & 1712 & 15.71 \\
Treatment dummy $\left(d^{c}\right)$ & 7.53 & 0.43 \\
Before/after dummy $\left(d^{a}\right)$ & 41.22 & 6.35 \\
Interaction $\left(d^{c} d^{a}\right)$ & -13.51 & -1.48 \\
Log Market Value of Equity $(m)$ & -79.11 & -14.20 \\
Return volatility $(\sigma)$ & 31.97 & 2.05 \\
Volume $(v)$ & 352 & 2.08 \\
\hline
\end{tabular}

Table 5: Regression results from estimating the difference-in-difference model

$$
s_{i t}=\alpha_{0}+\alpha_{1} d_{i}^{c}+\alpha_{2} d_{t}^{a}+\alpha_{3} d_{i}^{c} d_{t}^{a}+\alpha_{4} m_{i t}+\alpha_{5} \sigma_{i t}+\alpha_{6} v_{i t}+\epsilon_{i t} .
$$

The dependent variable, $s_{i t}$, the the average daily inside spread for firm firm $i$ on day $t$ in basis points. The dummy variable $d^{c}$ is 1 if the firm is in the treatment group (did become anonymous) and 0 otherwise. The dummy variable $d^{a}$ is 1 if the observation occurs after the anonymity event on June 2, 2008 and 0 if the observation occurs before that date. For firm $i$ on day $t, m_{i t}$ is the logarithm of the market value of equity in Euro, $\sigma_{i t}$ is the daily volatility of returns using quote midpoints sampled every 15 minutes, and $v_{i t}$ is volume of shares traded in billions of Euro. Since errors may be serially as well as cross-sectionally correlated we use the correction for standard errors clustered by both time and firm that was used for the quoted spread regressions (Thompson (2011)).

\subsection{Price Impact}

To compute the price impact of a trade, we only use trades that occur after 10:00 A.M. and before 4:25 P.M. and we drop any quotes that have a bid or ask price less than 
or equal to zero or that have bid-ask spread greater that $50 \%$ of the quote midpoint. Each trade is matched with the midpoint of the immediately preceding quote, $m_{t}$. The trade is also matched with the midpoint of the next quote that is at least five minutes after the trade occurs, $m_{t+5}$, and the price impact for that particular trade is computed as the percentage change of quote midpoints, $\left(m_{t+5}-m_{t}\right) / m_{t}$. If no quote can be found within 30 minutes of a trade then the trade is not used for computing price impact.

Large trades, defined as those above the median trade size for firm $i$ on day $t$ are separated from small trades, defined as those that are below the median for that firmday. Also trades that are buyer-initiated (occur at the ask) are separated from those that are seller-initiated (occur at the bid). This results in four categories of trades, large buys (LB), small buys (SB), large sells (LS), and small sells (SS) whose price impacts are averaged for each firm on each day. For the descriptive results in Table 6 and the regression analysis in Table 7 , any days in which there are fewer than 10 trades for a particular firm are dropped from the sample ${ }^{8}$.

The summary statistics for the sample are shown in Table 6. Each firm has two observations: The daily price impact averaged for the 54 days before the event and the 58 days after the event. Since the price impacts may be serially correlated, this is done so that unbiased t-statistics can be computed. More efficient estimates are computed in the regression estimation of a difference-in-difference model in the next section. The statistics in the table are in basis points. For example in panel A large buys (LB) before the event in the group of stocks that subsequently became anonymous were associated with an average increase in the midpoint of the bid-ask spread of 23.7 basis points subsequent to the trade.

For both the treatment and control groups the average price impacts are symmetric around zero: buys have a positive price impact and sells have a negative impact. Most

\footnotetext{
${ }^{8}$ When the analysis is repeated using all the trades the statistical inferences do not change.
} 
of the price impacts are significantly different from zero but to avoid cluttering the table these are not highlighted in Table 6. In panels A, B, C, and D, 15 of 16, 11 of 16, 15 of 16 and 14 of 16 are significantly different from 0 , respectively. The difference between small and large trades is not statistically significant; this is due to the small sample size that results from time-series averaging. For example, in the treatment group of the lowest market cap tercile after the anonymity event, large (small) sells had a average price impact of $-31.2(-6.1)$ basis points, but there are only about 30 firms in these groups with a standard deviation of the price impact of roughly 200 basis points.

Comparing the price impact before $(b)$ and after $(a)$ the event for all firms in panel A. The price impact of buys (sells) in both the anonymous and non-anonymous group becomes more positive (negative) after the event, suggesting an exogenous event that affects both groups of stocks and illustrating the need to have a control sample. Comparing the price impact across stocks that became anonymous (columns $t$ ) and those that remain non-anonymous (columns $c$ ) for all firms in panel A we find that compared to the non-anonymous group, the price impact for sells of stocks in the anonymous group is more positive and smaller in absolute value, while the comparison of the price impact for buys between the two groups is mixed, suggesting that buys and sells behave somewhat differently.

To understand the impact of post-trade anonymity, we compute a difference-indifference shown in the lower-right corner of panel A. For example, while the price impact of large buys in the treatment group (23.7) was smaller than the control group (28.9) before the event, after the event it was larger (37.5 compared to 34.0) resulting in a difference-in-diff of $(28.9-23.7)-(37.5-34.0)=8.8$, suggesting that making trades post-trade anonymous increases the price impact of large buys. While the difference-indifference suggests that the price impact of both buys and sells becomes more positive, since the price impact of sells was negative to begin with the net effect is that the price 
impact of sells is reduced while the price impact for buys gets larger in magnitude.

To see if the price impact effect is robust across firm size, firms are sorted into three market-cap terciles, with a mean firm size of 29, 147 and 3,430 Million Euro for the small, medium and large firm-size groups, respectively and the price impact is compared for firms in each of the three terciles in Panels B, C, and D of Table 6. In general, the same pattern holds as in panel A, however the magnitude of the effect both in the absolute value of price impact, the difference before and after the event (row $a-b$ ) and the differences between the anonymous and non-anonymous firms (columns $t-c$ ) for the smallest firms is largest for smaller firms, However, the number of differences that are statistically significant increases for the larger firms: Since there are more trades the price impact can be more precisely measured. 
Panel A: Price impact in basis points for all firms

\begin{tabular}{|c|c|c|c|c|c|c|c|c|c|c|c|c|}
\hline & \multicolumn{4}{|c|}{$\begin{array}{l}\text { Anonymous } \\
(\text { treatment, } t)\end{array}$} & \multicolumn{4}{|c|}{$\begin{array}{l}\text { Non-anonymous } \\
\quad(\text { control, } c)\end{array}$} & \multicolumn{4}{|c|}{$\begin{array}{l}\text { Difference } \\
\qquad(t-c)\end{array}$} \\
\hline & LB & SB & $\mathrm{LS}$ & SS & LB & SB & $\mathrm{LS}$ & SS & LB & SB & LS & SS \\
\hline Before $(b)$ & 23.7 & 9.8 & -14.8 & -15.3 & 28.9 & 29.8 & -24.6 & -26.7 & -5.2 & $-20.0^{*}$ & 9.8 & 11.4 \\
\hline After $(a)$ & 37.5 & 35.0 & -15.5 & -13.5 & 34.0 & 29.3 & -37.7 & -34.2 & 3.6 & 5.7 & $22.1^{*}$ & 20.8 \\
\hline$(a-b)$ & 13.8 & $25.2^{*}$ & -0.7 & 1.9 & 5.0 & -0.4 & $-13.0^{*}$ & -7.5 & 8.8 & 25.7 & 12.3 & 9.4 \\
\hline$N$ & 141 & 143 & 143 & 140 & 402 & 394 & 404 & 395 & & & & \\
\hline
\end{tabular}

Panel B: Price impact in basis points for lowest market cap tercile, MVE $=29$ million Euro

\begin{tabular}{|c|c|c|c|c|c|c|c|c|c|c|c|c|}
\hline & \multicolumn{4}{|c|}{$\begin{array}{c}\text { Anonymous } \\
(\text { treatment, } t)\end{array}$} & \multicolumn{4}{|c|}{$\begin{array}{l}\text { Non-anonymous } \\
(\text { control, } c)\end{array}$} & \multicolumn{4}{|c|}{$\begin{array}{l}\text { Difference } \\
\quad(t-c)\end{array}$} \\
\hline & LB & SB & LS & SS & LB & SB & LS & SS & LB & SB & LS & SS \\
\hline Before $(b)$ & 43.5 & 15.0 & -22.1 & -23.4 & 58.3 & 53.6 & -48.5 & -35.2 & -14.8 & -38.6 & 26.4 & 11.9 \\
\hline $\operatorname{After}(a)$ & 92.9 & 104.4 & -31.2 & -6.1 & 64.6 & 35.7 & -75.7 & -56.1 & 28.4 & 68.6 & 44.6 & 50.0 \\
\hline$(a-b)$ & 49.4 & $89.4^{*}$ & -9.0 & 17.3 & 6.2 & -17.9 & -27.2 & -20.8 & 43.2 & 107.2 & 18.2 & 38.1 \\
\hline$N$ & 32 & 34 & 34 & 31 & 97 & 93 & 97 & 90 & & & & \\
\hline
\end{tabular}

Panel C: Price impact in basis points for middle market cap tercile, MVE $=147$ million Euro

\begin{tabular}{|c|c|c|c|c|c|c|c|c|c|c|c|c|}
\hline & \multicolumn{4}{|c|}{$\begin{array}{c}\text { Anonymous } \\
\text { (treatment, } t)\end{array}$} & \multicolumn{4}{|c|}{$\begin{array}{l}\text { Non-anonymous } \\
\quad(\text { control, } c)\end{array}$} & \multicolumn{4}{|c|}{$\begin{array}{l}\text { Difference } \\
(t-c)\end{array}$} \\
\hline & LB & SB & LS & SS & LB & SB & LS & SS & LB & SB & LS & SS \\
\hline Before $(b)$ & 15.6 & 10.1 & -17.5 & -9.7 & 27.2 & 30.9 & -27.3 & -37.4 & $-11.7^{*}$ & $-20.8^{*}$ & 9.8 & $27.7^{*}$ \\
\hline $\operatorname{After}(a)$ & 30.4 & 19.7 & -14.7 & -29.2 & 31.7 & 43.4 & -37.3 & -41.9 & -1.4 & $-23.6^{*}$ & 22.6 & 12.7 \\
\hline$(a-b)$ & 14.8 & 9.7 & 2.8 & -19.5 & 4.5 & 12.5 & -10.0 & -4.5 & 10.3 & -2.8 & 12.7 & -15.0 \\
\hline$N$ & 46 & 46 & 46 & 46 & 142 & 140 & 144 & 142 & & & & \\
\hline
\end{tabular}

Panel D: Price impact in basis points for highest market cap tercile, MVE $=3,430$ million Euro

\begin{tabular}{|c|c|c|c|c|c|c|c|c|c|c|c|c|}
\hline & \multicolumn{4}{|c|}{$\begin{array}{c}\text { Anonymous } \\
(\text { treatment, } t)\end{array}$} & \multicolumn{4}{|c|}{$\begin{array}{l}\text { Non-anonymous } \\
(\text { control, } c)\end{array}$} & \multicolumn{4}{|c|}{$\begin{array}{l}\text { Difference } \\
(t-c)\end{array}$} \\
\hline & LB & SB & LS & $\mathrm{SS}$ & LB & SB & LS & SS & LB & SB & $\mathrm{LS}$ & $\mathrm{SS}$ \\
\hline Before $(b)$ & 19.7 & 6.8 & -8.9 & -15.4 & 13.0 & 15.1 & -8.1 & -12.7 & 6.7 & $-8.3^{*}$ & -0.8 & -2.7 \\
\hline $\operatorname{After}(a)$ & 8.3 & 4.8 & -6.9 & -5.2 & 14.5 & 11.8 & -11.1 & -12.8 & $-6.2^{*}$ & $-7.0^{*}$ & 4.2 & $7.7^{*}$ \\
\hline$(a-b)$ & -11.4 & -2.0 & 2.1 & 10.3 & 1.6 & -3.3 & -3.0 & -0.1 & -13.0 & 1.3 & 5.1 & 10.4 \\
\hline$N$ & 63 & 63 & 63 & 63 & 163 & 161 & 163 & 163 & & & & \\
\hline
\end{tabular}

Table 6: Average daily price impact in basis points of buyer and seller initiated trades for those firms that became anonymous on June 2, 2008 (the treatment group) and those firms that did not become anonymous (the control group) before and after the event date. "LB" and "SB" refer to large buys (above the daily median trade size for a firm) and small buys, respectively. "LS" and "SS" are defined similarly for large and small sells. Results are shown for all firms and for firms sorted by market value of equity terciles. A “*” indicates the statistic is significantly different from zero at the $5 \%$ level. 
Similar to the analysis on quoted spreads, we use a regression to estimate a differencein-difference model to determine if switching to anonymity had a significant effect on the price impact of a trade:

$$
p i_{i t}=\alpha_{0}+\alpha_{1} d_{i}^{c}+\alpha_{2} d_{t}^{a}+\alpha_{3} d_{i}^{c} d_{t}^{a}+\alpha_{4} m_{i t}+\alpha_{5} \sigma_{i t}+\alpha_{6} v_{i t}+\epsilon_{i t} .
$$

The dependent variable, $p i_{i t}$, is the average daily percentage price impact for buyer or seller initiated trades for firm firm $i$ on day $t$. The dummy variable $d^{c}$ is 1 if the firm is in the treatment group (did become anonymous) and 0 otherwise. The dummy variable $d^{a}$ is 1 if the observation occurs after the anonymity event on June 2, 2008 and 0 if the observation occurs before that date. The other right-hand side variables are the same ones used in in the spread regressions in Table 5: the logarithm of the market value of equity $(m)$, the volatility of returns $(\sigma)$, and volume $(v)$ are control variables. Errors may be serially as well as cross-sectionally correlated so we use the correction for standard errors clustered by both time and firm that was used for the quoted spread regressions (Thompson (2011)).

Since the results in Table 6 suggest that there is not much difference between large and small trades, for these regressions we combine small and large trades together. Coefficient estimates for two regressions using the price impact of buys and sells as the dependent variable are shown in Table 7 . As with the Table 6 , we only keep firm-days where there are at least 10 or more trades per day. This results in 32,000 observations used for each the regression. While the coefficient on market value of equity is not significant as suggested by the descriptive statistics in Table 6 , the coefficient on volume is positive and significant in both regressions. Since volume and size are positively correlated and the volume is subsuming the effect of firm size.

The coefficients on the variables in the regression of the price impact of seller-initiated 
trades, are consistent with Table 6 . The positive, though not significant, coefficient on the treatment dummy indicates that the stocks that became anonymous have a higher price impact than firms that did not. and the negative coefficient on the before/after dummy indicates the price impact became more negative after the event. The positive coefficient on firm size control corresponds to larger firms having a less negative price impact and the negative coefficient on volume corresponds to a more negative price impact for highervolume firms. The corresponding coefficients for the regression of buyer-initiated trades in general have the opposite sign but less significance.

The main coefficient of interest is $\alpha_{3}$ which represents how much the the price impact changed for those firms that became anonymous after June 2, 2008 relative to those firms that did not. The coefficient estimate of for seller-initiated trades is 3.94 and is statistically significant, indicating that anonymity decreased the price impact, in the senses that it became less negative, of these trades by 4 basis points. in contrast, the coefficient for buyer initiated trades is positive but not statistically different from 0 . 


\begin{tabular}{lrrrrr}
\hline & \multicolumn{2}{c}{ Buys } & & \multicolumn{2}{c}{ Sells } \\
\cline { 2 - 3 } \cline { 6 - 7 } Variable & $\begin{array}{r}\text { Coefficient } \\
\text { estimate }\end{array}$ & t-stat & & $\begin{array}{r}\text { Coefficient } \\
\text { estimate }\end{array}$ & t-stat \\
\hline Constant & 124.66 & 11.64 & & -101.77 & -9.47 \\
Treatment dummy $\left(d^{c}\right)$ & -8.09 & -3.89 & & 2.54 & 1.42 \\
Before/after dummy $\left(d^{a}\right)$ & -1.61 & -0.90 & & -3.09 & -2.03 \\
Interaction $\left(d^{c} d^{a}\right)$ & 1.92 & 0.97 & & 3.94 & 2.25 \\
Log Market Value of Equity $(m)$ & -5.30 & -9.82 & & 4.47 & 8.36 \\
Return volatility $(\sigma)$ & 2.10 & 1.71 & & -1.08 & -1.05 \\
Volume $(v)$ & 15.57 & 1.18 & & -26.16 & -2.13 \\
\hline R-squared & 0.0253 & & & 0.0151 & \\
Number of observations & 32,736 & & & 32,330 & \\
\hline
\end{tabular}

Table 7: Regression results from estimating the difference-in-difference model

$$
p i_{i t}=\alpha_{0}+\alpha_{1} d_{i}^{c}+\alpha_{2} d_{t}^{a}+\alpha_{3} d_{i}^{c} d_{t}^{a}+\alpha_{4} m_{i t}+\alpha_{5} \sigma_{i t}+\alpha_{6} v_{i t}+\epsilon_{i t} .
$$

The dependent variable, $p i_{i t}$, is the average daily price impact in basis points for buyer or seller initiated trades for firm firm $i$ on day $t$. The dummy variable $d^{c}$ is 1 if the firm is in the treatment group (did become anonymous) and 0 otherwise. The dummy variable $d^{a}$ is 1 if the observation occurs after the anonymity event on June 2, 2008 and 0 if the observation occurs before that date. For firm $i$ on day $t, m_{i t}$ is the logarithm of the market value of equity in Euro, $\sigma_{i t}$ is the daily volatility of returns using quote midpoints sampled every 15 minutes, and $v_{i t}$ is volume of shares traded in billions of Euro. Since errors may be serially as well as cross-sectionally correlated we use the correction for standard errors clustered by both time and firm that was used for the quoted spread regressions (Thompson (2011)). 
While the signs of the regression results in Table 7 agree with the sorts in Table 6 , the magnitudes don't agree. For example, the difference-in-difference estimates of the price impact of seller initiated trades in panel A of Table 6 are 12.3 (9.4) basis points for small (large) trades while the coefficient on the interaction term in the regression in Table 7 is 3.94. The price impact estimates in Table 6 were computed by averaging daily price impacts for each firm for the 54 days before and the 58 days after the event yielding two observations per firm - in order to obtain unbiased t-statistics. Since small firms are not as likely to have an observation each of the 54 (58) days before (after) the event, they will tend to be over-weighted in the results in panel A of Table 6. To illustrate this, Table 8 replicates the sorts using a firm-day as a unit of observation. The difference-in-difference estimates for seller initiated trades are 3.9 (3.4) basis points for the small (large) trades, agreeing with the estimated change in price impact of 3.94 basis points from the regression.

\begin{tabular}{|c|c|c|c|c|c|c|c|c|c|c|c|c|}
\hline & \multicolumn{4}{|c|}{$\begin{array}{c}\text { Anonymous } \\
(\text { treatment, } t)\end{array}$} & \multicolumn{4}{|c|}{$\begin{array}{l}\text { Non-anonymous } \\
\quad(\text { control, } c)\end{array}$} & \multicolumn{4}{|c|}{$\begin{array}{c}\text { Difference } \\
(t-c)\end{array}$} \\
\hline & LB & SB & LS & $\mathrm{SS}$ & LB & SB & LS & $\mathrm{SS}$ & LB & SB & $\mathrm{LS}$ & $\mathrm{SS}$ \\
\hline Before $(b)$ & 9.5 & 6.7 & -8.5 & -7.7 & 18.3 & 20.2 & -10.3 & -17.7 & -8.8 & -13.5 & 1.8 & 9.9 \\
\hline $\operatorname{After}(a)$ & 10.9 & 7.0 & -8.3 & -6.3 & 18.0 & 19.0 & -14.0 & -19.7 & -7.1 & -12.0 & 5.7 & 13.4 \\
\hline$(a-b)$ & 1.4 & 0.3 & 0.2 & 1.4 & -0.3 & -1.2 & -3.7 & -2.0 & 1.7 & 1.5 & 3.9 & 3.4 \\
\hline$N$ & 4,541 & 4,546 & 4,506 & 4,506 & 13,096 & 12,304 & 13,037 & 12,226 & & & & \\
\hline
\end{tabular}

Table 8: Average daily price impact in basis points of buyer and seller initiated trades for those firms that became anonymous on June 2, 2008 (the treatment group) and those firms that did not become anonymous (the control group) before and after the event date. "LB" and "SB" refer to large buys (above the daily median trade size for a firm) and small buys, respectively. "LS" and "SS" are defined similarly for large and small sells. 


\section{Conclusion}

We investigate the effects of introducing post-trade anonymity in a market that was previously post-trade transparent. Our sample comes from the NASDAQ OMX Nordic Exchange which introduced post-trade anonymity for some of its markets in June 2008. We exploit this quasi-natural experimental setting to make inference using difference-indifference regression methods. Using difference-in-difference, we find a modest, though statistically insignificant, 14 basis point improvement in the quoted spread under the post-trade anonymous regime. The price impact of a trade decreased by a statistically significant four basis points for seller-initiated trades and did not change for buyerinitiated trades. Taken together, the switch to anonymity did not hurt and, in fact, slightly improved market quality.

In future versions of this paper we will examine in more detail the stocks that are traded across two or more of NASDAQ OMX Nordic's satellite markets to learn more from these experiments. For example, some stocks that are listed on both Stockholm and Helsinki exchanges fall outside the top five group on the Stockholm exchange and hence become anonymously trade in Helsinki but remain transparent in Stockholm. 


\section{Appendix}

As Bertrand et al. (2004) point out, when OLS is used to estimate a difference-indifference model, the standard errors can be biased downward due to correlated errors in either the time-series or cross-section. Thompson (2011) shows how to correct for this and Table 9 shows the effect of not using the correct standard errors.

\begin{tabular}{|c|c|c|c|c|c|}
\hline Variable & $\begin{array}{c}\text { Coefficient } \\
\text { estimate }\end{array}$ & $\begin{array}{c}(1) \\
\text { None } \\
\text { t-stat }\end{array}$ & $\begin{array}{c}(2) \\
\text { Date } \\
\text { t-stat }\end{array}$ & $\begin{array}{c}\text { (3) } \\
\text { Firm } \\
\text { t-stat }\end{array}$ & $\begin{array}{c}(4) \\
\text { Date \& firm } \\
\text { t-stat }\end{array}$ \\
\hline Constant & 1712 & 98.19 & 65.70 & 15.96 & 15.71 \\
\hline Treatment dummy $\left(d^{c}\right)$ & 7.53 & 2.45 & 2.99 & 0.42 & 0.43 \\
\hline Before/after dummy $\left(d^{a}\right)$ & 41.22 & 16.96 & 10.06 & 7.36 & 6.35 \\
\hline Interaction $\left(d^{c} d^{a}\right)$ & -13.51 & -2.88 & -3.51 & -1.42 & -1.48 \\
\hline Log Market Value of Equity $(m)$ & -79.11 & -89.84 & -59.25 & -14.44 & -14.20 \\
\hline volatility $(\sigma)$ & 31.97 & 15.62 & 14.25 & 2.14 & 2.05 \\
\hline Volume $(v)$ & 352 & 6.79 & 5.22 & 2.16 & 2.08 \\
\hline
\end{tabular}

Table 9: Regression results from estimating the difference-in-difference model

$$
s_{i t}=\alpha_{0}+\alpha_{1} d_{i}^{c}+\alpha_{2} d_{t}^{a}+\alpha_{3} d_{i}^{c} d_{t}^{a}+\alpha_{4} m_{i t}+\alpha_{5} \sigma_{i t}+\alpha_{6} v_{i t}+\epsilon_{i t} .
$$

Four treatment of errors are shown: (1) no clustering, (2) clustering by date, (3) clustering by firm, and (4) clustering by date and firm. The variable definitions are the same as in Table 5. Briefly, $s_{i t}$, the the average daily inside spread, $d^{c}$ is 1 if the firm is in the treatment group (did become anonymous), $d^{a}$ is 1 if the observation occurs after the anonymity event on June $2,2008, m_{i t}$ is the logarithm of the market value of equity in Euro, $\sigma_{i t}$ is the daily volatility of returns, and $v_{i t}$ is volume of shares traded in billions of Euro.

The t-statistics in column (1) are computed with robust standard errors but no clustering and those in column (2) are clustered by date. In both these cases the standard errors are biased low and all coefficients are significant. The t-statistics in column (3) are clustered by firm, those in column (4) are clustered by date and firm. Those in column (4) are the ones reported in Table 5 and are corrected using the method in Thompson (2011). In both cases (3) and (4) the standard errors are larger and the coefficients on the treatment dummy and interacted dummies lose significance. In this case the t-statistics 
obtained by clustering by firm are almost identical to those obtained by clustering by date, but with knowing ex-ante that this was the case clustering by both firm and date is the most conservative method to estimate standard errors. 


\section{References}

Angrist, Joshua D., and Jörn-Steffen Pischke, 2009, Mosly Harmless Econometrics-An Empiriscist's Companion, first edition (Princeton University Press, Princeton, NJ).

Bertrand, Marianne, Esther Duflo, and Sendhil Mullainathan, 2004, How much should we trust differences-in-differences estimates?, Quarterly Journal of Economics 119, 249-276.

Card, David, and Alan Krueger, 1994, Minimum wages and employment: A case study of the fast-food industry in new jersey and pennsylvania, American Economic Review $84,772-793$.

Comerton-Forde, Carole, Alex Frino, and Vito Mollica, 2005, The impact of limit order anonymiy on liquidity: Evidence from paris, tokyo, and korea, Journal of Economics and Bussiness 57, 528-540.

Comerton-Forde, Carole, Talis J. Putnis, and Kar Mei Tang, 2011, Why do traders choose to trade anonymously?, Journal of Financial and Quantitative Analysis 46, 1025-1049.

Comerton-Forde, Carole, and Kar Mei Tang, 2009, Anonymity, liquidity and fragmentation, Journal of Financial Markets 12, 337-367.

Derrien, Francios, and Ambrus Kecskes, 2013, The real effects of financial shocks: Evidence from endogenous changes in analyst coverage, Journal of Finance 68, 1407-1440.

Fishman, Michael, and Kethleen Hagerty, 1995, The mandatory disclosure of trades and liquidity, Review of Financial Studies 8, 636-676.

Foucault, Thierry, Sophie Moinas, and Erik Theissen, 2007, Does anonymity matter in electronic limit order markets?, Review of Financial Studies 20, 1707-1747.

Foucault, Thierry, Marco Pagano, and Ailsa Röell, 2013, Market Liqudity: Theory, Evidence, and Policy, first edition (Oxford University Press, Oxford, UK).

Friederich, Sylvain, and Richard Payne, 2011, Trading anonymity and predatory behaviour, Working Paper, University of Bristol and Cass Business School .

Frino, Alex, David Johnstone, and Hui Zhang, 2010, Anonymity, stealth trading, and the information content of broker identity, The Financial Review 45, 501-522.

Grammig, Joachim, Dirk Schiereck, and Erik Theissen, 2001, Knowing me, knowing you: Trader anonymity and informed trading in parallel markets, Journal of Financial Markets 4, 385-412.

Grossman, Sanford, and Joseph Stiglitz, 1980, On the impossibility of informationally efficient markets, American Economic Review 70, 393-408. 
Hachmeister, Alexandra, and Dirk Schiereck, 2010, Dancing in the dark: Post-trade anonymity, liquidity and informed trading, Review of Quantitative Finance and Accounting 34, 145-177.

Huddart, Steven, John S. Hughes, and Carolyn B. Levine, 2001, Public disclosure and dissimulation of insider trades, Econometrica 69, 665-681.

Kyle, Albert, 1985, Continuous auctions and insider trading, Econometrica 53, 13151335.

Lepone, A., Reuben Segara, and Brad Wong, 2012, Does broker anonymity hide informed traders?, in J. Jay Choi, and Heibatollah Sami, eds., Transparency and Governance in a Global World, 287-217 (Emerald, Bingley, U.K.).

Linnainmaa, Juhani, and Gideon Saar, 2012, Lack of anonymity and the inference from order flow, Review of Financial Studies 25, 1414-1456.

Marsden, Aistair, Russell Poskitt, and Jingfei Shen, 2011, The impact of the introduction of broker anonymity on the new zealand exchange, Pacific Accounting Review 23, 3451.

Menkhoff, Lukas, and Mail Schmeling, 2010, Trader see, trader do: How do (small) fx traders react to large counterparties's trades?, Journal of International Money and Finance 29, 1263-1302.

Pham, Thu Phuong, 2014, Broker id transparency and price impact of trades: Evidence from the korean exchange, International Journal of Managerial Finance, forthcoming.

Pham, Thu Phuong, Peter Swan, and P. Joakim Westerholm, 2014, Shining a spotlight on counterparty identity in the world's best-lit market, Unpublished Manuscript .

Rindi, Barbara, 2008, Informed traders as liquidity providers: Anonymity, liquidity and price formation, Review Finance 12, 1-36.

Simaan, Yusif, Daniel Weaver, and David Whicomb, 2003, Market maker quotation behavior and pretrade transparency, Journal of Finance 58, 1247-1267.

Thompson, Samuel B., 2011, Simple formulas for standard errors that cluster by both firm and time, Journal of Financial Economics 99, 1-10. 


\section{Earlier Working Papers:}

For a complete list of Working Papers published by Sveriges Riksbank, see www.riksbank.se

Estimation of an Adaptive Stock Market Model with Heterogeneous Agents

Some Further Evidence on Interest-Rate Smoothing: The Role of Measurement Errors in the Output Gap

by Mikael Apel and Per Jansson

Bayesian Estimation of an Open Economy DSGE Model with Incomplete Pass-Through

by Malin Adolfson, Stefan Laséen, Jesper Lindé and Mattias Villani

Are Constant Interest Rate Forecasts Modest Interventions? Evidence from an Estimated Open Economy

DSGE Model of the Euro Area

by Malin Adolfson, Stefan Laséen, Jesper Lindé and Mattias Villani

Inference in Vector Autoregressive Models with an Informative Prior on the Steady State

by Mattias Villani

Bank Mergers, Competition and Liquidity

by Elena Carletti, Philipp Hartmann and Giancarlo Spagnolo

Testing Near-Rationality using Detailed Survey Data

by Michael F. Bryan and Stefan Palmqvist

Exploring Interactions between Real Activity and the Financial Stance

2005:184

by Tor Jacobson, Jesper Lindé and Kasper Roszbach

Two-Sided Network Effects, Bank Interchange Fees, and the Allocation of Fixed Costs

2005:185

by Mats $A$. Bergman

Trade Deficits in the Baltic States: How Long Will the Party Last?

2005:186

by Rudolfs Bems and Kristian Jönsson

Real Exchange Rate and Consumption Fluctuations follwing Trade Liberalization

by Kristian Jönsson

Modern Forecasting Models in Action: Improving Macroeconomic Analyses at Central Banks

by Malin Adolfson, Michael K. Andersson, Jesper Lindé, Mattias Villani and Anders Vredin

Bayesian Inference of General Linear Restrictions on the Cointegration Space

by Mattias Villani

Forecasting Performance of an Open Economy Dynamic Stochastic General Equilibrium Model

2005:190

by Malin Adolfson, Stefan Laséen, Jesper Lindé and Mattias Villani

Forecast Combination and Model Averaging using Predictive Measures

2005:191

by Jana Eklund and Sune Karlsson

Swedish Intervention and the Krona Float, 1993-2002

2006:192

by Owen F. Humpage and Javiera Ragnartz

A Simultaneous Model of the Swedish Krona, the US Dollar and the Euro

2006:193

by Hans Lindblad and Peter Sellin

Testing Theories of Job Creation: Does Supply Create Its Own Demand?

2006:194

by Mikael Carlsson, Stefan Eriksson and Nils Gottfries

Down or Out: Assessing The Welfare Costs of Household Investment Mistakes

2006:195

by Laurent E. Calvet, John Y. Campbell and Paolo Sodini

Efficient Bayesian Inference for Multiple Change-Point and Mixture Innovation Models

2006:196

by Paolo Giordani and Robert Kohn

Derivation and Estimation of a New Keynesian Phillips Curve in a Small Open Economy

2006:197

by Karolina Holmberg

Technology Shocks and the Labour-Input Response: Evidence from Firm-Level Data

2006:198

by Mikael Carlsson and Jon Smedsaas

Monetary Policy and Staggered Wage Bargaining when Prices are Sticky

2006:199

by Mikael Carlsson and Andreas Westermark

The Swedish External Position and the Krona

by Philip R. Lane 
Using a New Open Economy Macroeconomics model to make real nominal exchange rate forecasts 
Evaluating Microfoundations for Aggregate Price Rigidities: Evidence from Matched Firm-Level Data on

Flexible Modeling of Conditional Distributions Using Smooth Mixtures of Asymmetric

Student T Densities

by Feng Li, Mattias Villani and Robert Kohn

Forecasting Macroeconomic Time Series with Locally Adaptive Signal Extraction

Risk Premiums and Macroeconomic Dynamics in a Heterogeneous Agent Model by Ferre De Graeve, Maarten Dossche, Marina Emiris, Henri Sneessens and Raf Wouters

Picking the Brains of MPC Members

by Mikael Apel, Carl Andreas Claussen and Petra Lennartsdotter

Involuntary Unemployment and the Business Cycle

by Lawrence J. Christiano, Mathias Trabandt and Karl Walentin

Housing collateral and the monetary transmission mechanism

by Karl Walentin and Peter Sellin

The Discursive Dilemma in Monetary Policy

by Carl Andreas Claussen and Øistein Røisland

Monetary Regime Change and Business Cycles

Bayesian Inference in Structural Second-Price common Value Auctions

by Bertil Wegmann and Mattias Villani

Equilibrium asset prices and the wealth distribution with inattentive consumers

by Luca Sala, Ulf Söderström and Antonella Trigari

Density-Conditional Forecasts in Dynamic Multivariate Models

by Michael K. Andersson, Stefan Palmqvist and Daniel F. Waggoner

Anticipated Alternative Policy-Rate Paths in Policy Simulations

by Stefan Laséen and Lars E. O. Svensson

MOSES: Model of Swedish Economic Studies

by Gunnar Bårdsen, Ard den Reijer, Patrik Jonasson and Ragnar Nymoen

The Effects of Endogenuos Firm Exit on Business Cycle Dynamics and Optimal Fiscal Policy

by Lauri Vilmi

Parameter Identification in a Estimated New Keynesian Open Economy Model 
The Cost of Consumer Payments in Sweden

by Björn Segendorf and Thomas Jansson

Trade Credit and the Propagation of Corporate Failure: An Empirical Analysis

by Tor Jacobson and Erik von Schedvin

Structural and Cyclical Forces in the Labor Market During the Great Recession: Cross-Country Evidence

by Luca Sala, Ulf Söderström and AntonellaTrigari

Pension Wealth and Household Savings in Europe: Evidence from SHARELIFE

by Rob Alessie, Viola Angelini and Peter van Santen

Long-Term Relationship Bargaining

by Andreas Westermark

Using Financial Markets To Estimate the Macro Effects of Monetary Policy: An Impact-Identified FAVAR*

by Stefan Pitschner

DYNAMIC MIXTURE-OF-EXPERTS MODELS FOR LONGITUDINAL AND DISCRETE-TIME SURVIVAL DATA

by Matias Quiroz and Mattias Villani

Conditional euro area sovereign default risk

by André Lucas, Bernd Schwaab and Xin Zhang

Nominal GDP Targeting and the Zero Lower Bound: Should We Abandon Inflation Targeting?*

by Roberto M. Billi

Un-truncating VARs*

by Ferre De Graeve and Andreas Westermark

Housing Choices and Labor Income Risk

by Thomas Jansson

Identifying Fiscal Inflation*

by Ferre De Graeve and Virginia Queijo von Heideken

On the Redistributive Effects of Inflation: an International Perspective*

by Paola Boel

Business Cycle Implications of Mortgage Spreads* 
Sveriges Riksbank

Visiting address: Brunkebergs torg 11

Mail address: se-103 37 Stockholm

Website: www.riksbank.se

SVERIGES Telephone: +46 878700 00, Fax: +46 8210531

RIKSBANK E-mail: registratorn@riksbank.se 